reprocessing plant in a country like Pakistan-which is planning on deriving almost half its energy supply from nuclear sources by the end of the century. Even the $2,000 \mathrm{MW}$ from the big earth-filled Tarbela dam, he claimed, would be insignificant in filling the country's energy gap. And oil-fired power stations were becoming less viable, especially as Pakistan had so far struck almost no ail or good quality coal. So, the only option, according to Mr Munir Ahmad, would be the nuclear one.

His view is that in the overall nuclear fuel economy framework, reprocessing of used fuel plus plutonium is inescapable. Jacques Couture, sales manager of the reprocessing division of the French company, Compagnie Generale des Matiere Nuclearies, has not missed his opportunity to blow the re- processing trumpet. He has said that "with a typical light-water reactor which needs about 180 tonnes of natural uranium a year, the annual saving will be at least 40 tonnes, or even 70 tonnes if the plutonium recovered during reprocessing as well as the uranium is recycled." In fast breeder reactors, the fuel is some $20 \%$ plutonium oxide in uranium oxide, and the nuclear expert's view here is that a co-processing plant that cannot deliver plutonium is, therefore, not of much value, seen in that context.

Mr Munir Ahmad was vehement in his address on the topic of proliferation. He said that the safeguard imposed by IAEA had been fully incorporated in the agreement and that the French had imposed some additional safeguards. He saw no valid reason for the scepticism which had been shown, and thought it might not be unfair to conclude that the motive for changing the agreement was to deny a developing country a useful, sophisticated technology of future.

Pakistan has sizable deposits of uranium and thorium-bearing minerals. Pakistani scientists are exploring the possibility of exploiting the indigenous sources of thorium in a thoriumuranium-233 cycle in fast breeder reactors, for which plutonium is essential.

The French have developed a proliferation-free uranium enrichment process--a chemical exchange methodbut it is unlikely to be commercially viable for another decade or so. Likewise, the French concept of the coprocessing plant has yet to be commercially accepted as it has not been tried in any other country.

Axim Kidwai

\section{Europe's nuclear circus}

Plenty of shadow-boxing went on at last week's open discussions on nuclear energy organised by the European Commission, with no side quite hitting home but nevertheless a lot of energy expended. The proceedings were launched by news of an accident at one of Belgium's nuclear plants on 13 January. The accident was made public by the Environmental Protection Society who claimed that 80 people were contaminated by radium-131 and that the affair had been covered up by government authorities.

The news caused quite a scare in Belgium, but was ridiculed by speakers at the nuclear debate, doctors, and the director of the Tihange plant near Liège, where the leak occurred.

The so-called 'father of the $\mathrm{H}$ bomb', Dr Edward Teller, a leading US nuclear physicist at the Hoover Institute for War, Revolution, and Peace, Stanford, California, told the nuclear hearings panel and an audience of several hundred that he was 'more alarmed' at the kidnapping of Baron Edouard Empain in Paris by terrorists, than by the Belgian leak. The Hungarian-born scientist claimed that he had been exposed to more radiation when he flew over Europe to be present at the hearings.

The state-run electricity company, responsible for the Tihange plant, put the figure of people involved at between 30 and 60 . Director Robert Van den Damme said that no members of the public were involved during the accident which happened during an annual maintenance check. $\mathrm{He}$ said that workers ignored the leak until the job was done. Six people had to be examined by doctors, who they said had been contaminated by 100 millirems of radium-131. They added that the maximum tolerated dose was 3,000 millirems for 13 weeks before the possibility of thyroid cancer occurred.

The Friends of the Earth argued that the principal issue was one of disclosure; that the authorities should have made the accident public and that their natural reaction had been to conceal it. But $\mathrm{Mr}$ Van den Damme denied that the affair had been hushed up. He said that the leak had not escaped from the plant and had therefore done no damage to the environment or the surrounding population. "It was not worthwhile to publish information about something that did not happen".

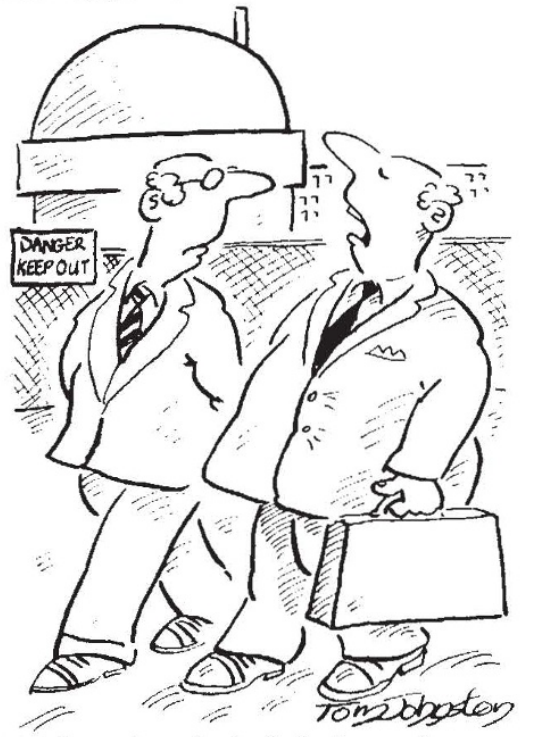

"If there is a leak, let's hope there are some terrorists in the area!"
The news did manage to give the Commission's nuclear hearings more relevance. The session ended after three days of heated debate between the supporters of nuclear energy and its critics. The highlight for many was described as a "confrontation" between two old debating partners, Robert Jungk, an Austrian futurologist opposed to the use of nuclear energy. and the controversial Dr Teller.

The theme of the session 'Economic growth and energy options: implications for safety, health and environmental protection', considered the problems of terrorist activities and the proliferation of nuclear weapons. Jungk argued that increased security measures to guard against the two problems could lead to centralisation and therefore police states. He said that this was a form of mental pollution that was not acceptable and advocated the immediate suspension of the nuclear energy programme.

Dr Teller hit back by describing what he termed as the worst possible pollution, that of poverty. He argued that the developed countries should devote their energy to developing nuclear power. He said that oil should be given to the third world to enable it to develop, whereas nuclear power was economically and structurally beyond its reach. And he put paid to terrorists by theatrically declaring that "the only way to get rid of terrorism is to get rid of terrorists".

The debate at least guaranteed a full house. EEC energy commissioner Guido Brunner made no final assessment of the findings of the hearings. Critics claim that there was never an intention of altering the Commission's approach to energy policy as a result of the debate.
Patricia Kelly 